Contents List available at RAZI Publishing

Malaysian Journal of Geosciences

Journal Homepage: http://www.razipublishing.com/journals/malaysian-journal-of-geosciences-mjg/

https://doi.org/10.26480/mjg.01.2017.13.26

\title{
Active Faults In Peninsular Malaysia With Emphasis On Active Geomorphic Features Of Bukit Tinggi Region
}

Mustaffa Kamal Shuib, Mohammad Abdul Manap, Felix Tongkul, Ismail Bin Abd Rahim, Tajul Anuar Jamaludin, Noraini Surip5, Rabieahtul Abu Bakar, Mohd Rozaidi Che Abas, Roziah Che Musa, Zahid Ahmad

1Department Of Geology, University of Malaya, 50603 Kuala Lumpur.Minerals and Geoscience Department Malaysia, Headquarters Bangunan Tabung Haji, Jalan Tun Razak, 50658 Kuala Lumpur.3School of science and technology, Universiti Malaysia Sabah, 88999 Kota Kinabalu, Sabah.4School of Environmental and Natural Resource Sciences, UniversitiKebangsaan Malaysia, Bangi. Selangor.5Faculty of Engineering, Technology \& Built Environment, UCSI University, 56000 Kuala Lumpur.6Malaysian remote Sensing Agency, JalanTun Ismail, 50480 Kuala Lumpur.7Malaysian Metereology Departmet. Jalan Sultan, 46667 Petaling Jaya, Selangor.

This is an open access article distributed under the Creative Commons Attribution License, which permits unrestricted use, distribution, and reproduction in any medium, provided the original work is properly cited.

\section{ARTICLE DETAILS \\ Article history: \\ Received 22 January 2017 \\ Accepted 03 February 2017 \\ Available online 05 February 2017}

Keywords:

Active faults, earthquakes, paleoearthquakes, Bukit Tinggi, tectonic landform.

\begin{abstract}
In this paper, we summarize the results of recent geomorphic investigations of active faults in Peninsular Malaysia with emphasize on Bukit Tinggi region using IFSAR and field verification. The evidences for active faulting, and their characteristics are discussed. Several fault segments within the Bukit Tinggi fault zone are deemed active. The Bukit Tingg fault zone is considered to be active and is a potential source of future earthquakes. Outside Bukit Tinggi area, the Benus and Karak faults are also deemed active. These fault zones show the following active neotectonic geomorphic features: 1) displays geomorphic features indicative of recent fault activity; 2) show evidence for displacement in young (Late Quaternary) deposits or surfaces; and/or 3) is associated with a pattern of microearthquakes suggestive of an active faults. They were ancient faults that were reactivated in the Quaternary period and continued into the present. The magnitude of paleoearthquake estimated from the activity and stream offsets suggest a minimum of 6 magnitude on the Richter scale have affected the region due to movements along these faults. Over the past decades, Peninsular Malaysia has experienced mild earthquakes. Virtually all earthquakes recorded in Peninsular Malaysia are under magnitude 5.0. However, the regognition of active faults exhibiting active tectonic landforms suggestes that these faults have produced damaging earthquakes before and have potential to trigger similar tremors in the future.
\end{abstract}

\section{Introduction}

Due to a lack of large, damaging earthquakes during historical time, Peninsular Malaysia has not been considered to be a seismically active country. However, it is still subjected to seismic hazards and not free from earthquake damage. However, there is no reliable, long-term earthquake record and an absence of historical fault surface ruptures. Therefore, it is necessary to examine the geologic and geomorphic record, in order to quantify the activity on suspected active faults, and thereby determine their contribution to the seismic hazards of the country. In this paper, we summarize the results of recent geomorphic investigations of active faults in Peninsular Malaysia with emphasize on Bukit Tinggi region using IFSAR with field verification.

The evidences for active faulting, and the characteristics of these faults are discussed. Several fault segments within the Bukit Tinggi fault zone are deemed active. The Bukit Tingg fault zone is considered to be active and is a potential source of future earthquakes. The fault zone show the following active neotectonic geomorphic features: 1) displays geomorphic features indicative of recent fault activity; 2) show evidence for displacement in young (Late Quaternary) deposits or surfaces; and/or 3) is associated with a pattern of microearthquakes suggestive of an active faults.

Tectonic setting

Peninsualr Malaysia (Figure 1) is situated on SUNDALAND, the southern protrusion of the Eurasian Plate. Sundaland is a region that comprised of the Malay Peninsula and Maritime Southeast Asia islands of Sumatra, Java, Borneo and surrounding smaller islands. It is situated at the core of Sundaland that has been considered a tectonically stable region since the Cenozoic. Generally, it is considered as tectonically stable with low seismicity profile. It experienced dam induced seismicity of low magnitude (less than 4.5 on the Richter scale) at Kenyir Dam in 1985

Seimic hazard

-Tremors from far-field earthquakes:

The peninsula is bounded by two of the most seismically active plate boundaries. To the west the inter-plate boundary between the IndoAustralian and Eurasian Plates defined by the Sunda Subduction Trench and the inter-plate boundary between Eurasian and Philippine Plates to the east Phillipines Subduction Trench. It is situated close to the most seismically active plate boundaries between the Indian-Australian Plate and Eurasian Plate in the west and between Philippine Plate and Eurasian Plate in the east. It occassionally experienced tremors due to earthquakes from these far-field sources.

-Tsunami:
In also did not escape the 2004 megathrust tsumani. The tsunami raised the alarm that the penisula is not free from seismic hazard.

\section{-Local earthquakes:}

Since 2007 the peninsula is experincing ocassional earthquakes of local origin for example the 2007-09 Bukit Tinggi earthquakes. These events stirred awareness among the public and authorities on the potential seismic hazard and risk faced by the peninsula.

Thus, empirical evidence suggests that Malaysia is not totally free from seismic risks. Recent seismicity in Peninsular Malaysia has been confined to low levels with no clear association with existing mapped faults. The identification of active faults is the subject of this study.

\section{Young active neotectonic defromation}

The identification of neotectonic deformation and active faults in Peninsular Malaysia has been hampered by:

\section{1) the comparative lack of fault studies;}

2) extensive weathering of bedrock and extremely active erosion acting together to prevent the preservation of all but the most resistant geomorphic features;

3) large areas of thick forest vegetation, and

4) the probable low slip rates of the intraplate faults in Peninsular Malaysia.

These factors result in a lack of recognizable, long-lived surface faulting geomorphic features. Despite these shortcomings, Quaternary deformation investigations in Peninsular Malaysia have been successful and indicate that it is ongoing and that these activity may pose a seismic hazard (e.g., JMG, 2008 and 2012). Lacking a well-defined Quaternary framework for Peninsular Malaysia, recent studies (e.g., JMG, 2008 and 2012) concentrated on the relationship of earhquake epicentres to geomorphic lineament expression of faulting, and the comparison with the features observed along other active faults in similar tectonic settings worldwide.

In Peninsular Malaysia Raj (1979) reported the presence of a Quaternary fault near Bentong Pahang. Tjia (2010) and Mustaffa Kamal Shuib (2011 \& 2012) summarized some evidences for Quaternary deformational activities onshore and offshore of Peninsular Malaysia. The evidences of active tectonic deformations include an Early Quaternary pillow-basalt flow near Kuantan on the eastern shore of the Peninsula is traversed by long fractures orientated parallel to faults in the pre-Tertiary basement. 
The fractures in the basalt are essentially vertical and are evident manifestations of reactivation of the older faults. In Southeast Johor at the edge of the Penyu basin, crustal uplift of $0.5-0.8 \mathrm{~m}$ during the past 5000 years is suggested by an abrasion platform that is that much higher compared to the eustatic Holocene sea-level curve of the Peninsula which was established from almost a hundred radiometrically determined bioshoreline indicators. In the northwest on the shores of Langkawi, a 2500year old abrasion platform is cut by a long fault zone whose associated secondary structures suggest sinistral displacement.

\section{Active major faults}

Generally, major fault in the Malay Peninsula (Figure 1) appeared to be inactive. However, a series of large earthquakes in recent years had changed the tectonic scenario in the Southeast Asian region, including the Peninsular Malaysia. In spite of its crustal stability, the 2004-Sumatera earthquake had caused horizontal shifts of GPS monuments in the Peninsula in the order of up to $7 \mathrm{~mm}$. There are also indications of co-seismic uplifts. In Langkawi, stacked doublets of (recently live specimens) barnacle-oyster bands suggest uplift in the order of half a meter by the same event. The Malay Basin region offshore the Peninsula is on stable crust, and yet seismic shows major, deepreaching faults to approach the seabed to within $150 \mathrm{~m}$, indicating activity on these structures to have persisted into the Pleistocene.

A series of seismic activities with local epicentres (Figure 1) occurred in the peninsular since 1978. From 1978 to 2006 Peninsular experirnced local earthquakes up to $4.6 \mathrm{Mw}$ (IRIS Earthquake Database). From 2007 to 2010 it experience earthqukes up to 4.2 Mw (MMD). The series of seismic activities is believed as preliminary indications of the reactivation of major faults in Peninsular Malaysia. Therefore, many believed that the reactivation of the faults system in Peninsular Malaysia was associated with the great Sumatra-Andaman Earthquake (26 December 2004), Nias Earthquake (28 March 2005) and Bengkulu Earthquake (12 September 2007). Subsequently, local earthquakes that had occurred in Bukit Tinggi (between 30 November 2007 to 25 May 2008), Jerantut (17 March 2009), Manjong (29 April 2009) and Kuala Pilah (29-30 November 2009) were associated with these events. Recently, the Southern Sumatra Earthquake that occurred on 30 September 2009 had reactivated the Bukit Tinggi Fault system, and caused a series of 7 weak local earthquakes around the Bukit Tinggi area (8 October and 4 December 2009). Another weak tremor of 2.6 magnitude was recorded on 10 March 2010 at $11.10 \mathrm{pm}$ local time, at Tasik Kenyir area at latitude $5.1^{\circ} \mathrm{N}$ and longitude $102.8^{\circ} \mathrm{E}, 43 \mathrm{~km}$ southwest of K.Terengganu, $22 \mathrm{~km}$ west of Kuala Berang.

A plot of the earthquake epicentres on the regional fault maps of Peninsular Malaysia is shown in figure 1 . The epicentres apparently seem to be diffusely distributed throughout the Peninsular, typical of intraplate seismicity. However in a closer look they seem to be close to and aligned along major faults. These epicentres were aligned along the NNW bukit Tinggi fault zone N-S Kenus and Karak faults (Bukit Tinggi epicentres), the NNW Lepar fault (Jerantur epicentre) , Bokbak fault zone (Baling epicentre), Mersing fault zone (mersing epicentre), Terengganu fault (Kenyir epicentre). These faults show prominent lineaments but does not show any surface rupture related to the present earthquakes. They are believed to have been reactivated to give rise to the local earthquakes

\section{Identification of active faults in Bukit Tinggi area}

\section{1) Earthquake epicentres and fault relationship}

In the Bukit Tinggi region (Figure 2 and 3), the epicentres are diffusely distributed arround Bukit Tinggi. Their distribution in relation to geology is shown in figure 4. They seem to align along NW-SE, NNE-SSW and N-S trends. They coincide with the major faults which are clearly seens as negative lineaments on SRTM and IFSAR (Figures 2 -4) images. They were found to coincide with the following lineaments: a) the Bukit Tinggi fault Zone lineamentgs (NW-SE), b) WNW trend within the Bukit Tinggi fault zone, c) E-W, d) NE and e) N-S trends,

They are bounded by the Bukit Tinggi and Hulu Kelang fault zones. Several of the epicenters are aligned parallel to the orientation of the Bukit Tinggi fault zone, which is northwest, and other epicenters follow the northerly Karak fault trend and some northeasterly trend. On SRTM, these fault zones appear as through-going structures. The Bukit Tinggi fault zone can be traced for a distance of more than $100 \mathrm{~km}$ between Kuala Kubu Bahru in the northwest to Kuala Kelawang in the southeast. Bukit Tinggi fault zone together with the Hulu Kelang-Kongkoi fault zone (Shu, 1989) it forms a fault zone about $7 \mathrm{~km}$ wide. The fault strikes 3100 to 3250 . To the southeast the Bukit Tinggi fault zone is deviated right-laterally by eastern strands of the Karak fault zone and merged with the Kongkoi fault zone near Kuala
Lumpur. The Bukit Tinggi fault zone shows left lateral displacements of two kilometres. Many hotsprings are located along these fault zones and their extension (figure 2). This suggests that the faults are deep seated. The focal mechanisms of the largest $3.5 \mathrm{mb}$ event along the Bukit Tinggi fault is mostly strike slip with some dip slip, while that of three events are strike slip fault type (Siti Norbaizura 2011).

The distribution of the epicentres within the viccinity of Bukit Tinng New Village on IFSAR is shown in Figure 5.The relationship the earthquake epicentres with the extracted lineaments is shown in Figure 6. Figure 7 shows the distance of epicenters from lineaments. The analysis noted that the earthquake epicenters are found diffuse in the vicinity along:

a) the Bukit Tinggi fault Zone trend (NW)

b) WNW trend along the Bukit Tinggi fault zone.

c) E-W and d) NE trends,

suggesting ongoing reacvtivation of these faults. This is consistent with the findings of JMG (2012) which suggest that the relationship of the recent earthquake epicentres with known faults as "established

\section{2) Geomorphic features of active faulting}

To determine the active segments of the faults it is necessary to analyze the geomorphology of the area. In this study, we applied digital enhanced IFSAR images (figure 5) for data analysis. The digital enhanced IFSAR images study and interpretation is to assist in delineating small-scale neotectonic features and to define the orientation and direction of the investigated active fault segments. Practically, automatic and visual interpretation was used. This is regarded as the prime and most effective approach for identification of neotectonic or active fault geomorphic features.

The following geomorphological features were picked up in the IFSAR analysis and verified in the field:

\section{a) Primary neotectonic features/ landforms}

Several morphotectonic pieces of evidence can be recognized from the IFSAR data. Among them, the most outstanding features are steep-sided basins, triangular facets and steep scarps.

\section{i) Steep-sided Quaternary alluvial basins.}

IFSAR analysis reveals several pieces of morphotectonic features such as steep-sided Quaternary alluvial basins with steep and faceted scarps. Figure 8, 9 and 10 shows the steep-sided Quaternary alluvial basins as mapped based on IFSAR. In Bukit Tinggi the basin trend NW along the Bukit Tinng fault zone. At Janda Baik area there are several narrow linear sub-parallel NE trending alluvial basins along the NE lineaments (Figure 8 ). When superimposed on lineament and fault maps (Figure 8 - 10), it is noted that the steep-sided basins are bounded by steep lineaments. Thus it is interpreted as fault scarps features. Within the basin the surface is cut by sub-parallel lineaments that define a terraced topography (figure 10). These suggest that the alluvial basin is fault-controlled and have undergone internal displacements suggesting the basin infillings were subjected to internal deformation.

Figure 11 shows a panoramic view of the alluvial plain bounded by steep scarps. Outcrops along the scarps reveal the presence of fine to coarse grain alluvial deposits (figure 12). These deposits contain large boulders at their base and exhibit warped bedding (figure 12A). These implied that the alluvium have undergone neotectonic deformations.

b) Secondary neotectonic features The drainage network derived from IFSAR DEM is shown in figure 13. It shows that the main drainage pattern is flowing from NW to SE. The distributaries flowed from N-S and from $\mathrm{W}$ to $\mathrm{E}$. From the drainage pattern it is noted that there are several places where the streams form dog-leg pattern. From the pattern it was noted that the dog-legs are due to stream off-sets, beheadments and shifting streams (figure 13 \& 14).

a) Stream off-sets (figure $13 \& 14$ ).) can be located at several places along the river at several localities. At these localities the stream has been shifted for about $500 \mathrm{~m}$ to form the dog-leg pattern. The offset line is generally extended on both sides along negative lineaments of about $5 \mathrm{~km}$ long bounded triangular facets with hour glass geometry typical of active faulting. One or two earthquake epicentres may aligned along the lineaments. These suggest young fault controlled on the stream offsets.

b) Shifting streams (figure 13\& 14). At one locality the major stream form dog-legged pattern due to stream offsets of about $600 \mathrm{~m}$. Along the offset region a small quaternary basin developed bonded by steep scarps. In addition to that it was found several parallel curvilinear abandoned 
streams (marked 1,2,and 3) arranged in an en-echelon manner marked the different stages of the offset movements as shown in figure 13 occur in the basin. These abandoned stream terminated along the shift / stream offset line which coincide with an earthquake epicenter location. This further support the presence of young fault movements along the offset line shifting the streams. During the progressing movements the old stream alignment was abandoned and the river took on a new course creating the shifting abandoned streams.

c)

Beheaded streams. Figure 13 \& 14 shows several examples of beheaded streams. These beheaded streams are defined as several distributary streams that were offset along an offset line and shifted into a single major stream. These are attributed to young fault movements along the offset line.

\section{Identification of active faults in Bentong- Karak area}

As shown earlier, several of the epicenters are aligned parallel to the orientation of the Bukit Tinggi fault zone, which is northwest, and other epicenters follow the northerly Benus and Karak fault zones trend. The Bentong and Karak fault zones (figure 15) occurring in the study area are clearly shown on the Shuttle Radar Topography Mission (SRTM) image as a $5 \mathrm{~km}$ wide northerly trending negative lineaments. It is bounded on the western side by a prominent N-S lineament passing through Taman Benus Jaya and to the east by another prominent $\mathrm{N}-\mathrm{S}$ lineament passing through Karak. The two bounding faults bounds several less prominent $\mathrm{N}-\mathrm{S}$ trending lineaments. The Karak Fault Zone trends 3500-3550-. In the northern part it pass and seem to terminate in Benmore tong-Karak area. It extension to the south passes through Kajang-Sg. Long area. The zone has a length of more than $55 \mathrm{~km}$ with a maximum width to the south of about $28 \mathrm{~km}$. The fault zone is a Right lateral (Tjia, 1972) fault. It is Intercept by Bukit Tinggi, Hulu Kelang and Kuala Lumpur fault zones.

No local earthquake epicentres are located in the area but in Bukit Tinggi area there are epicentres that are aligned $\mathrm{N}-\mathrm{S}$ along the trend of the major faults in this area. Young active movements along these faults are shown by stream offsets as shown in figures 16 and 17 . There are 2 fault traces that show features of young movements with continuous length of $4.5 \mathrm{~km}$ and $10.7 \mathrm{~km}$.Their outstanding features are very sharp bend (dog-leg) of the stream and distinct offsets and clear scarp facets. These offset streams occurring in this fault trace performs a sinistral (left-lateral)l offset of several hunded meter stream offsets

\section{DISCUSSION}

From this geomorphic study, we recognize both old and young faults Remote-sensing information clearly indicates that the old faults are the most prominent fault traces, as observed from field, and satellite images. These faults trends in the NW-SE, NE-SW and N-S directions. The NWSE Bukit Tinggi Fault and the N-S Benus and Karak Faults mostly follows the predated regional geological structures which developed prior to the Cenozoic times. Others interesting lineament features, which are regarded as old faults, are also observed in the east-west and northeast-southwest directions.

Within the Bukit Tinggi fault zone, IFSAR revealed the presence of Quaternary basins, and young geomorphic or active tectonic landforms such as stream offsets, beheaded streams, steep scarps and faceted spurs. They formed short lineaments that coincided with earrthquake epicentres. The are believed to be the surface menisfestation of active faults that occurred as short segments within the Bukit Tinggi fault zone. Most of these active fault segments trend NW_SE parallel to the main fault zone. Others trend WNW-ESE, and NNE-SSW. From the sense of offsets they exhibit both dip - slip and strike-slip movements with sinistral motions likely due to the secondary effect of the active movements along the Bukit Tinggi fault zone.

At Bentong and Karak area, the Benus and Karak faults also shows evidences of active faulting in the form of stream offsets. It is of particular interest that these recently reactivated faults produced active geomorphic features which were likely related to paleoearthquakes suggesteing that they are active faults. Based on the presence of active geomorphic features, the magnitude of the paleoearhquake that occurred must be not less than 6 on tghe Richter Scale.

Further study is in progress to determine the ages of these paleoearthquake occurence to determine their magnitude, slip rates and reccurrence intervals for seismic hazard and risk analysis.

\section{CONCLUSIONS}

In this research, It is concluded that there are several likely active faults in Peninsular Malaysia based on earthquake epicentres distribution. Present geomorphic study from satellite images and earthquake evidences clearly depicts that within the NW trending Bukit Tinggi fault zone, there are severa strands of both oblique and parallel active fault segments suggesting that the main Bukit Tinggi fault is an active fault. Offsets streams also suggest active faulting along the Benus and Karak faults.

They were ancient faults that were reactivated in the Quaternary period and continued into the present. The magnitude of paleoearthquake estimated from the activity and stream offsets suggest a minimum of 6 magnitude on the Richter scale have affected the region due to movements along these faults.

Over the past decades, Peninsular Malaysia has experienced mild earthquakes. Virtually all earthquakes recorded in Peninsular Malaysia are under magnitude 5.0. However, the regognition of active faults exhibiting active tectonic landforms suggestes that these faults have produced damaging earthquakes before and have potential to trigger similar tremors in the future.

\section{References}

1. Ben-Avraham, Z., Emery, K.O., 1973. Structural framework of Sunda Shelf. American Association of Petroleum Geologists Bulletin 57, 2323-2366.

2. Che Noorliza Lat, 1997a. Seismicity of Kenyir, Terengganu. Abstract. Warta Geologi. 23(3), 184-185.

3. Che Noorliza Lat, 1997b. Dam-induced seismicity of Kenyir Terengganu. Abstract. Warta Geologi. 23(2), 68.

4. Che Noorliza Lat, 2002. Reservoir Induced Seismicity (RIS): A Case Study from Kenyir Terengganu, Geophysical Contributions in the Environmental Studies and Conservation Seminar Proceedings (on CD), Geological Society Malaysia.

5. Gobbett, D.J. and Hutchison, C.S., 1973. Geology of the Malay Peninsula (West Malaysia and Singapore), Wiley-Interscience, New York $438 \mathrm{pp}$.

6. Mustaffa Kamal Shuib, 2008. A preliminary interpretation of the recent Bukit Tinggi earthquakes using SRTM DEM. Warta Geologi, 34(1), 5-7

7. Mustaffa Kamal Shuib (2009). The recent Bukit Tinggi earthquakes and its relationship to major structures . Geological Society of Malaysia, Bulletin 55, July 2009, pp. 1 - 6

8. Mustaffa Kamal Shuib. 2011. Evidences for recent seismicities and dating of active faulting in NW Peninsular Malaysia, NATIONAL GEOSCIENCE CONFERENCE 2011, 11 June 2011 to 12 June 2011, Geological Society of Malaysia.

9. Mustaffa Kamal Shuib. 2012. Paleoearthquakes and active faulting activities in Peninsular Malaysia. Seminar Teknikal Kebangsaan Gempabumi dan tsunami, Abstrak. Petaling Jaya 13-14 Disember 2012, Jabatan Metereologi Malaysia, www.met.gov.my/images/pdf/national.../ dr_mustaffa_abstract.pdf

10. Raj, J.K. (1979): A Quaternary fault in Peninsular Malaysia. Newsletter Geol. Soc. Malaysia, v.5, 3-5.

11. Siti Norbaizura Bt Mat Said (2011) Focal mechanism determinations of local earhquakes in Peninsular Malaysia. EARTHQUAKE TECHNICAL SEMINAR. DECEMBER 20.TH- 21ST, 2011. Metrological department of Malaysia.

12. Tjia, H.D., 1996. Sea-level changes in the tectonically stable Malay-Thai peninsula. Quaternary International 31, 95-101.

13. Tjia, H.D., 2010. Growing evidences of active deformation in the Malay Basin region. Bulletin of the Geological Society of Malaysia 56 (2010) 35 - 40, doi: 10.7186/bgsm2010005 http://geology.um.edu.my/ gsmpublic/BGSM/bgsm56/bgsm2010005.pdf 


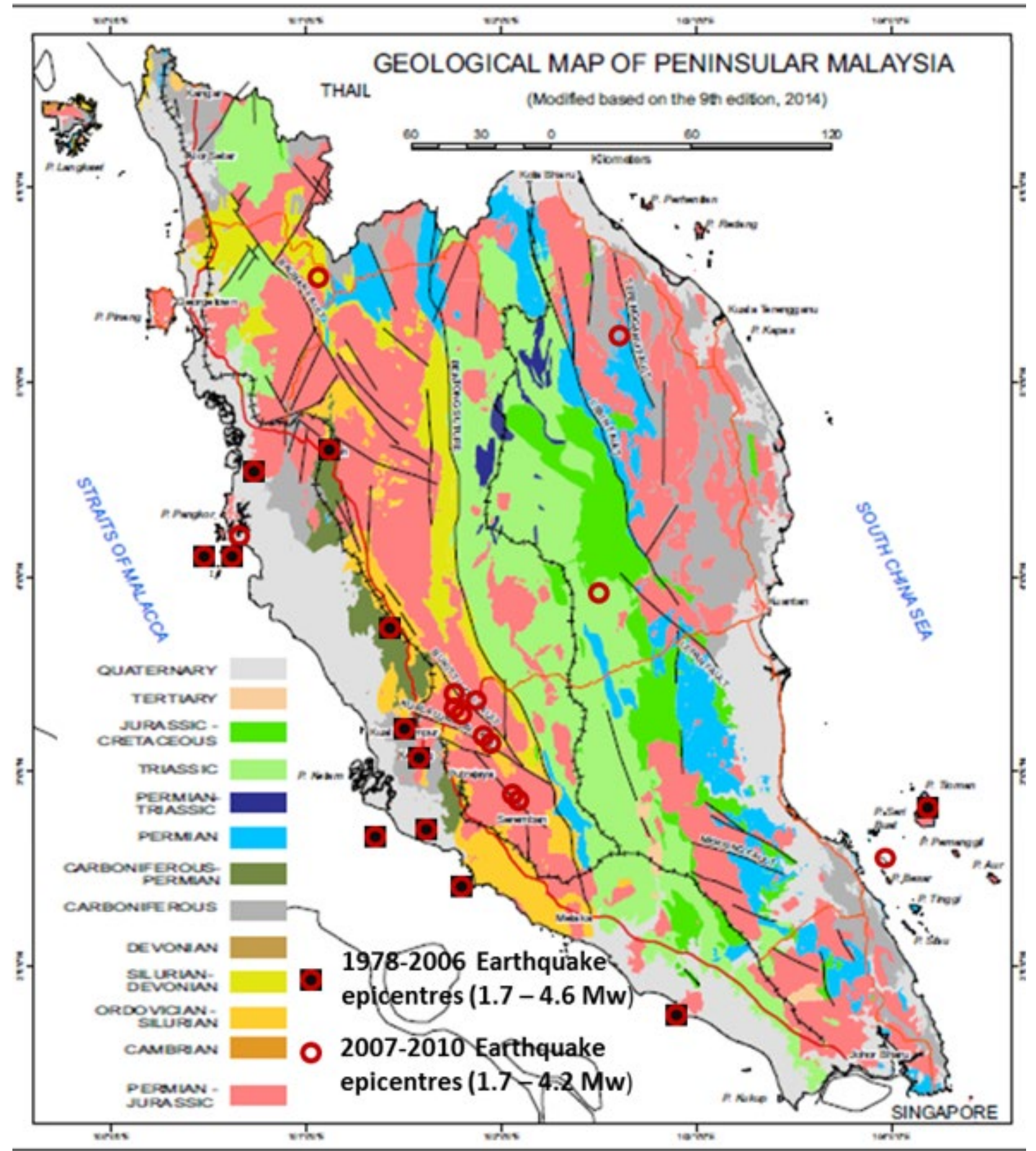

1 Geologic map map of Malay Peninsula (JMG, 2006) showing the distribution of local earthquake epicentres. 1. Bok B: : Fault, 3. Terengganu Fault, 4. Bukit Tinggi Fault, 5. Kuala Lumpur Fault, 6. Lepar Fault and 7. Mersing Fault. (geolog IG) 


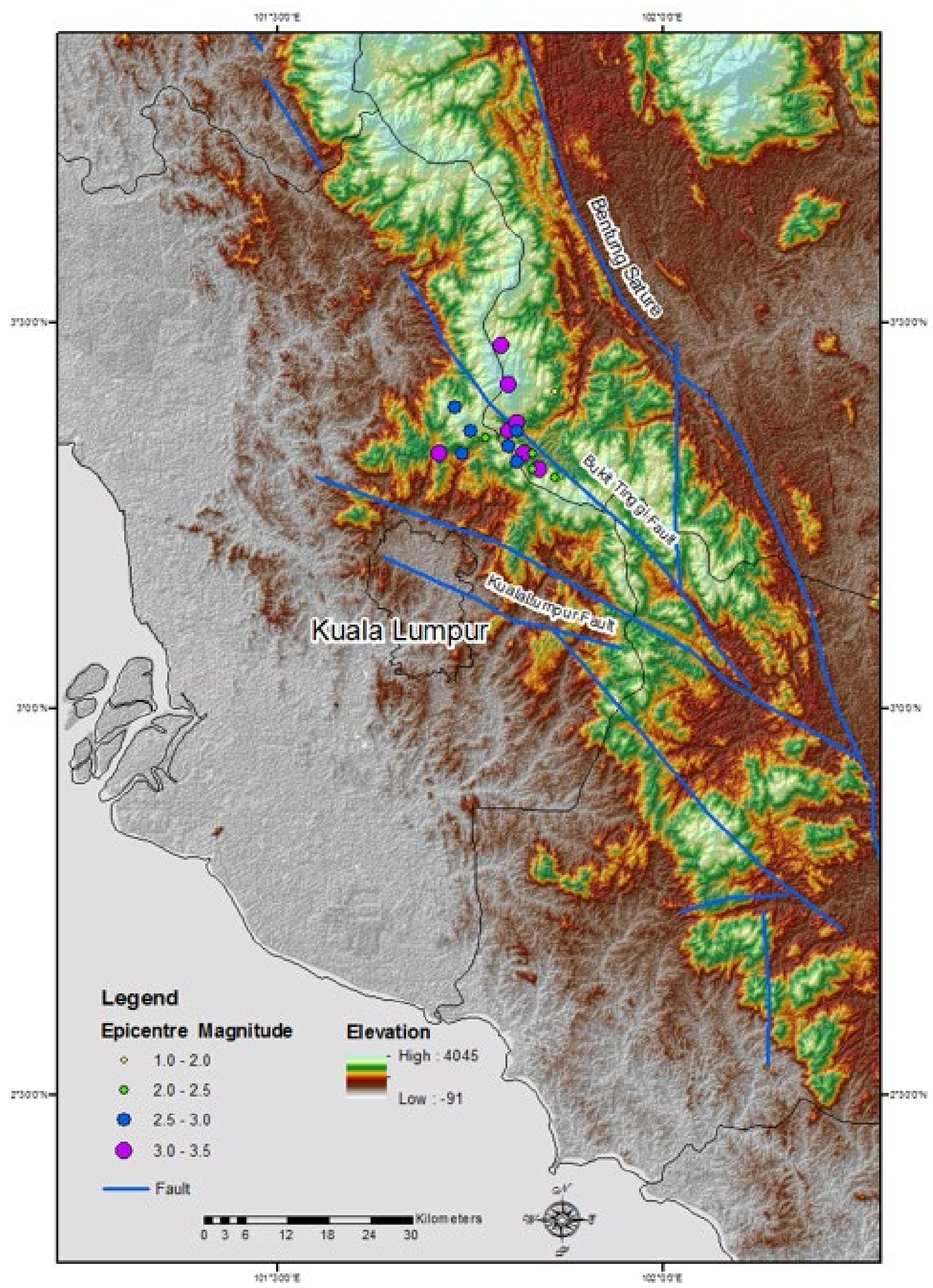

Figure 2 The relationship between earthquake epicentres with mapped fault as plotted on SRTM. 


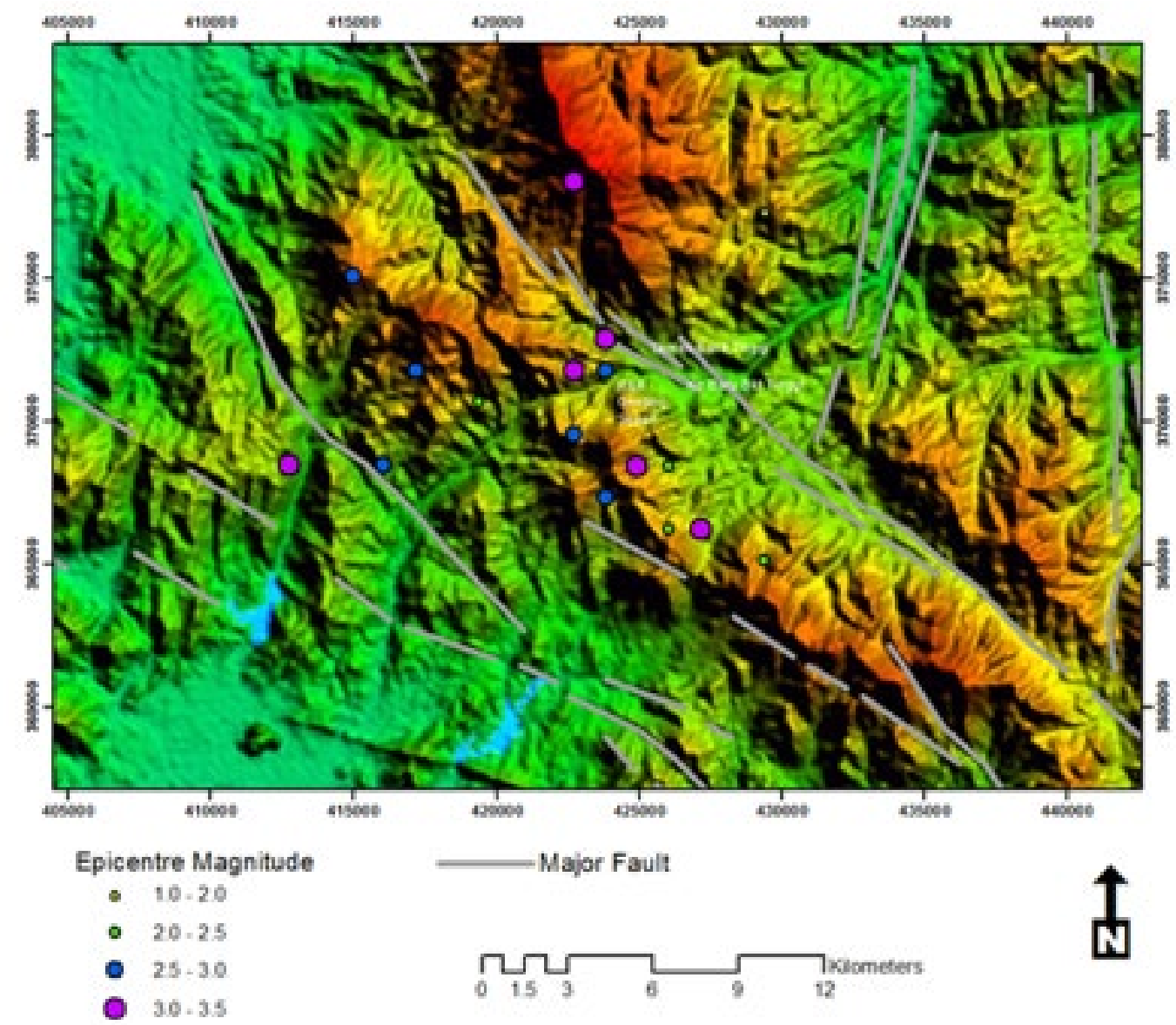

Figure 3 The relationship between earthquake epicentres with mapped faults in Bukit Tinng area as plotted on SRTM 


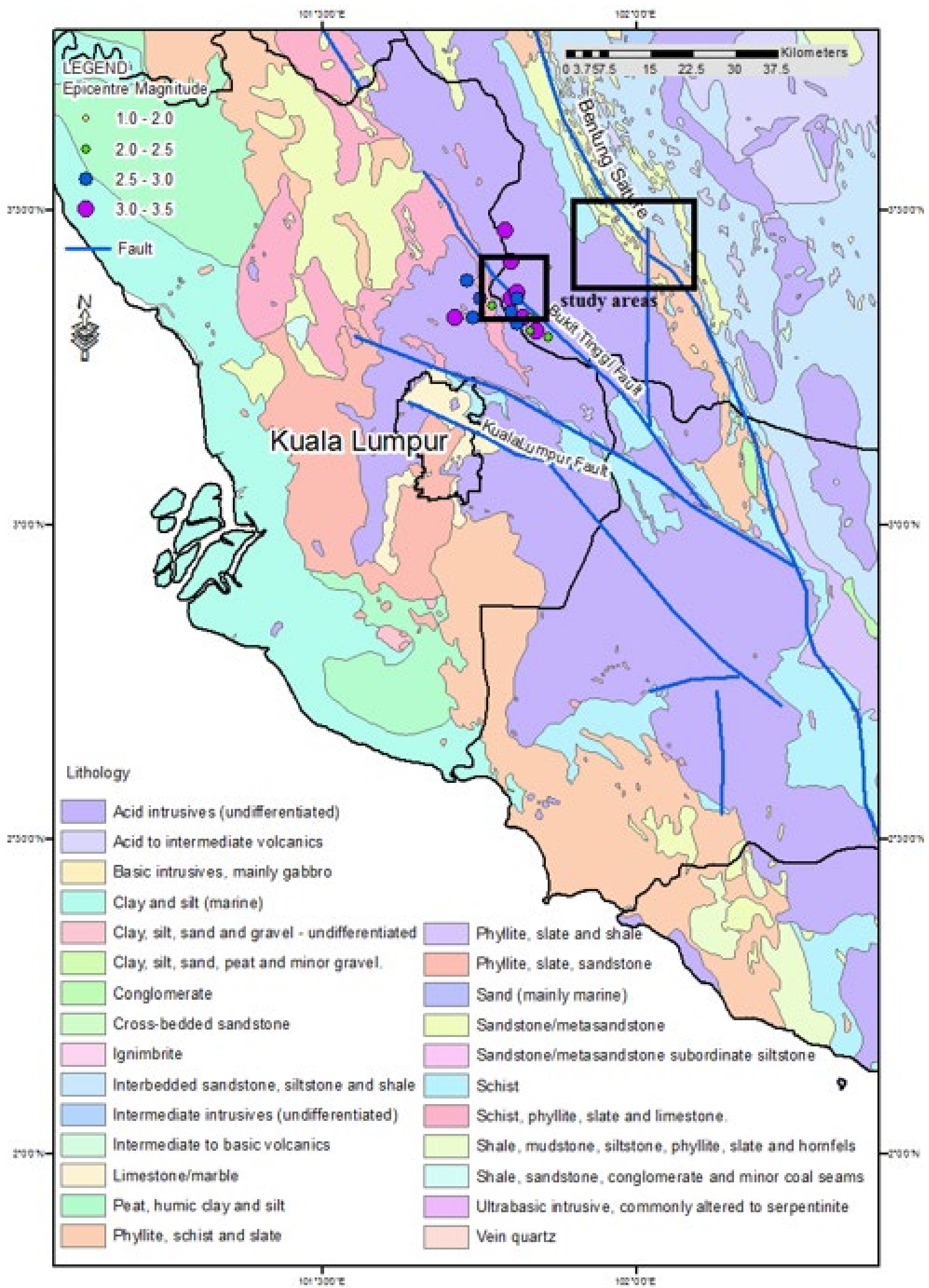




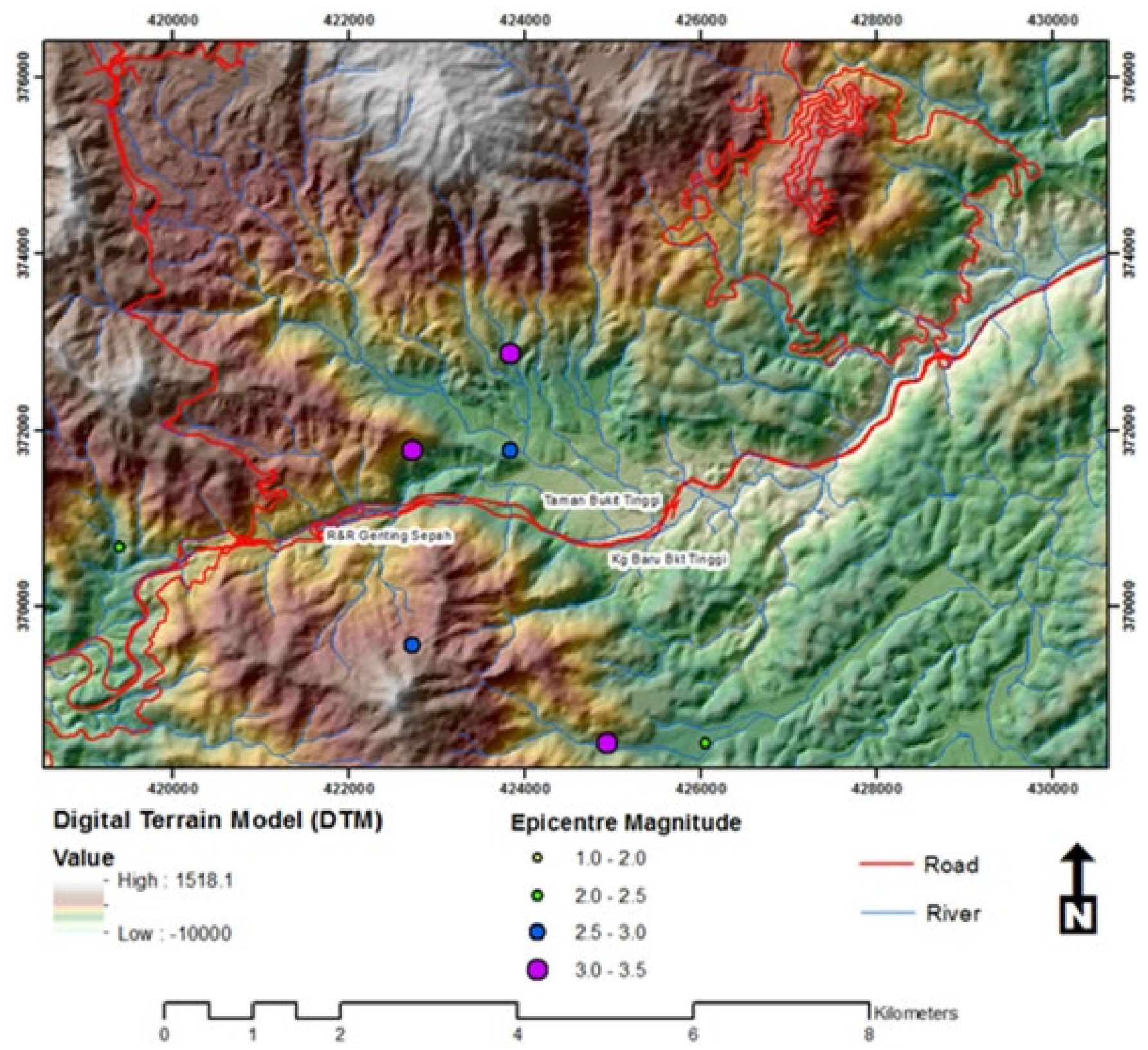

gure 5. IFSAR imagery of Bukit Tinggi area with epicentres localities. 


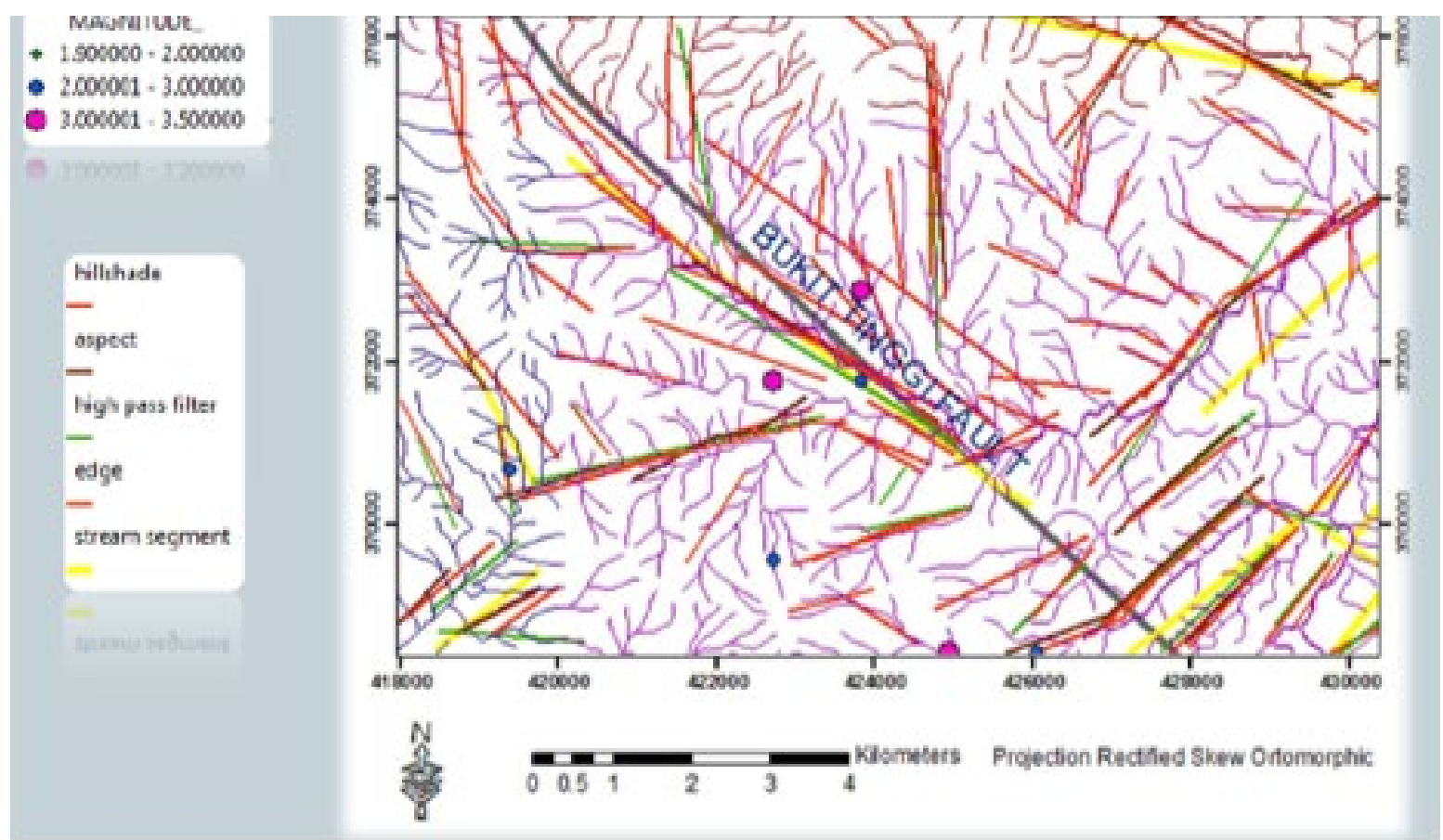

'igure 6 The relationship between epicentres and lineaments in the vicinity of Bukit Tinggi New Village interpreted from IFSAR

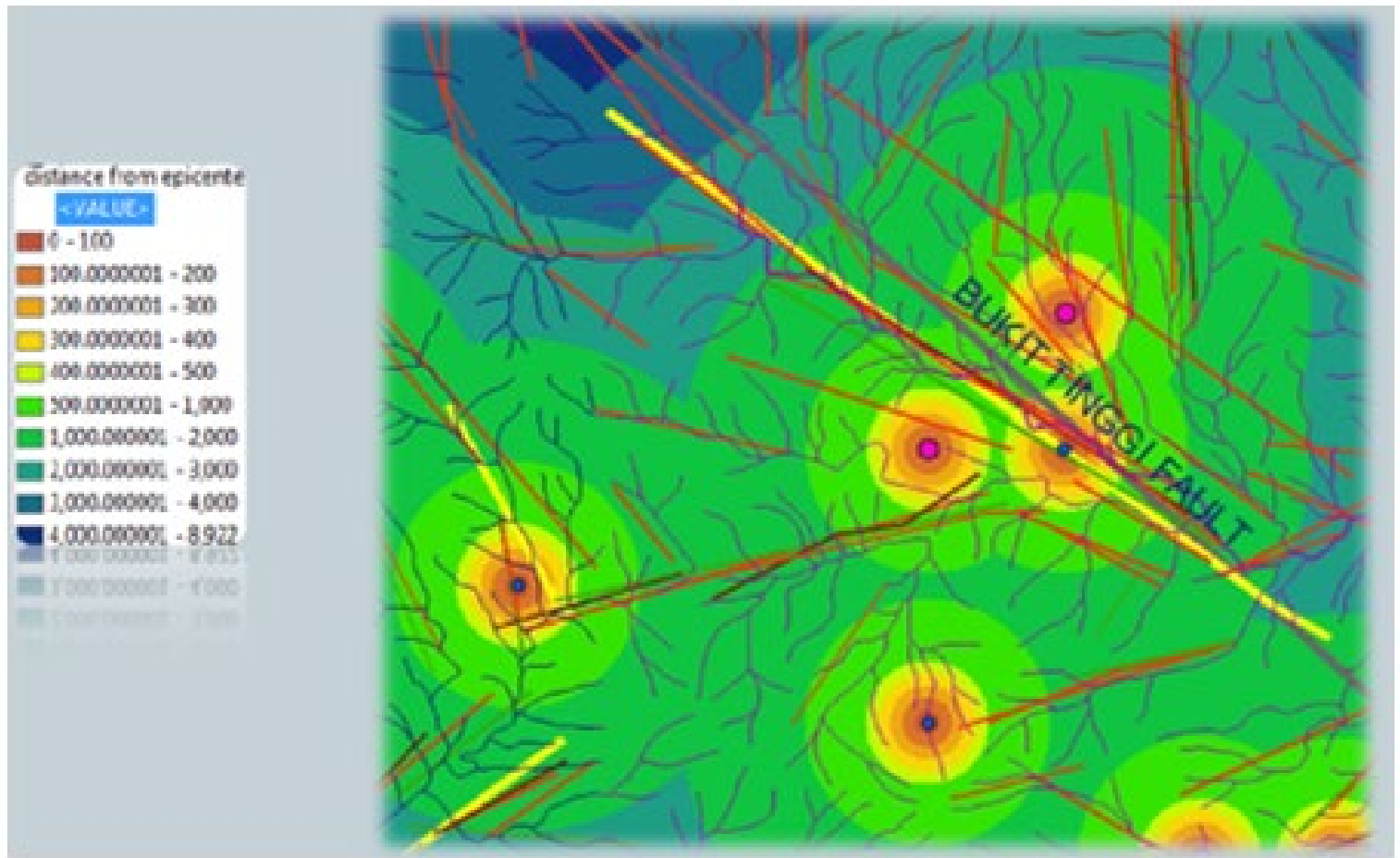

'igure 7. The distance relationship between epicentres and lineaments in the vicinity of Bukit Tinggi New Village on IFSAR 


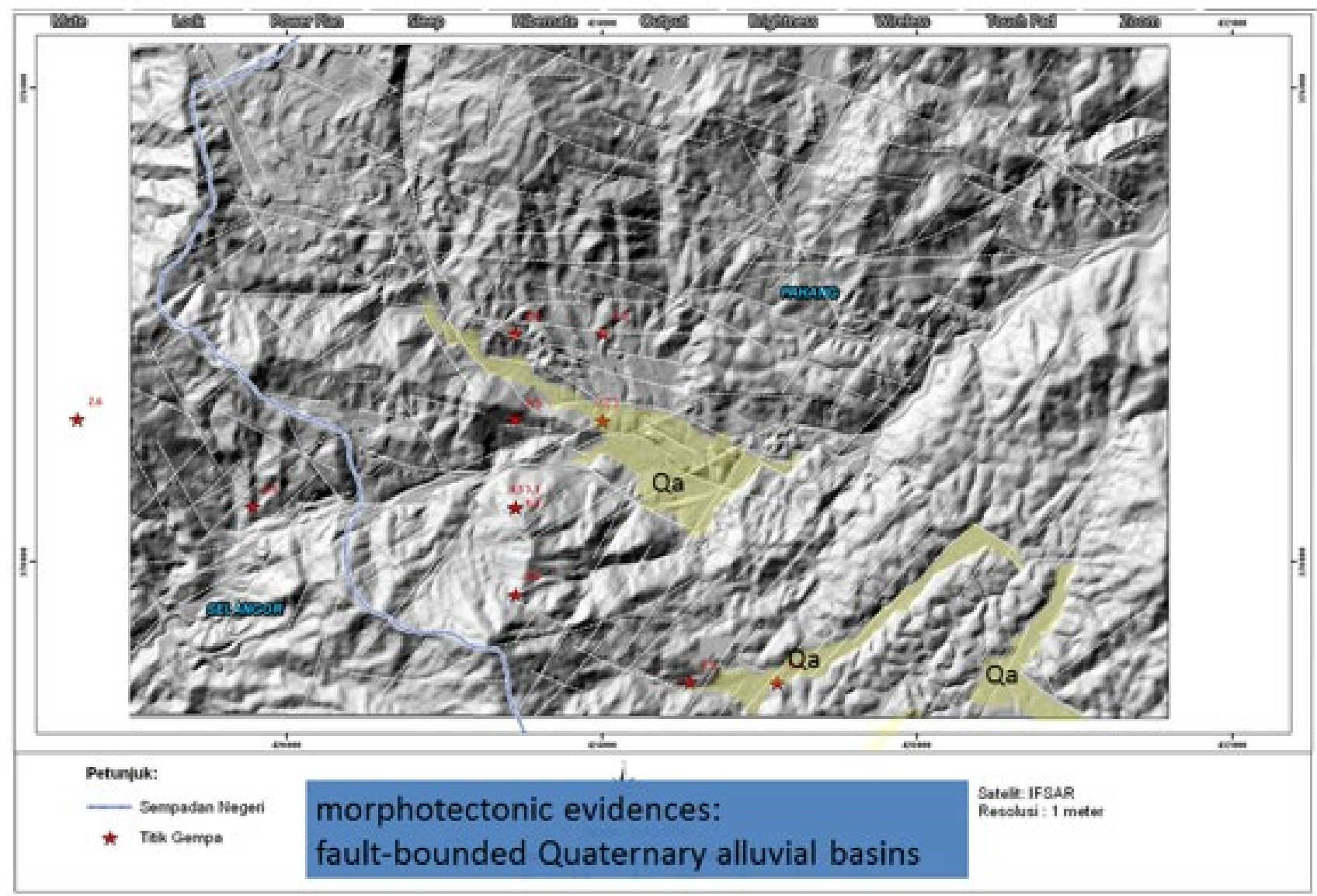

Figure 8. The distribution of alluvial basins (Qa) in the Bukit Tingg region, bounded by lineaments interpreted as faults.

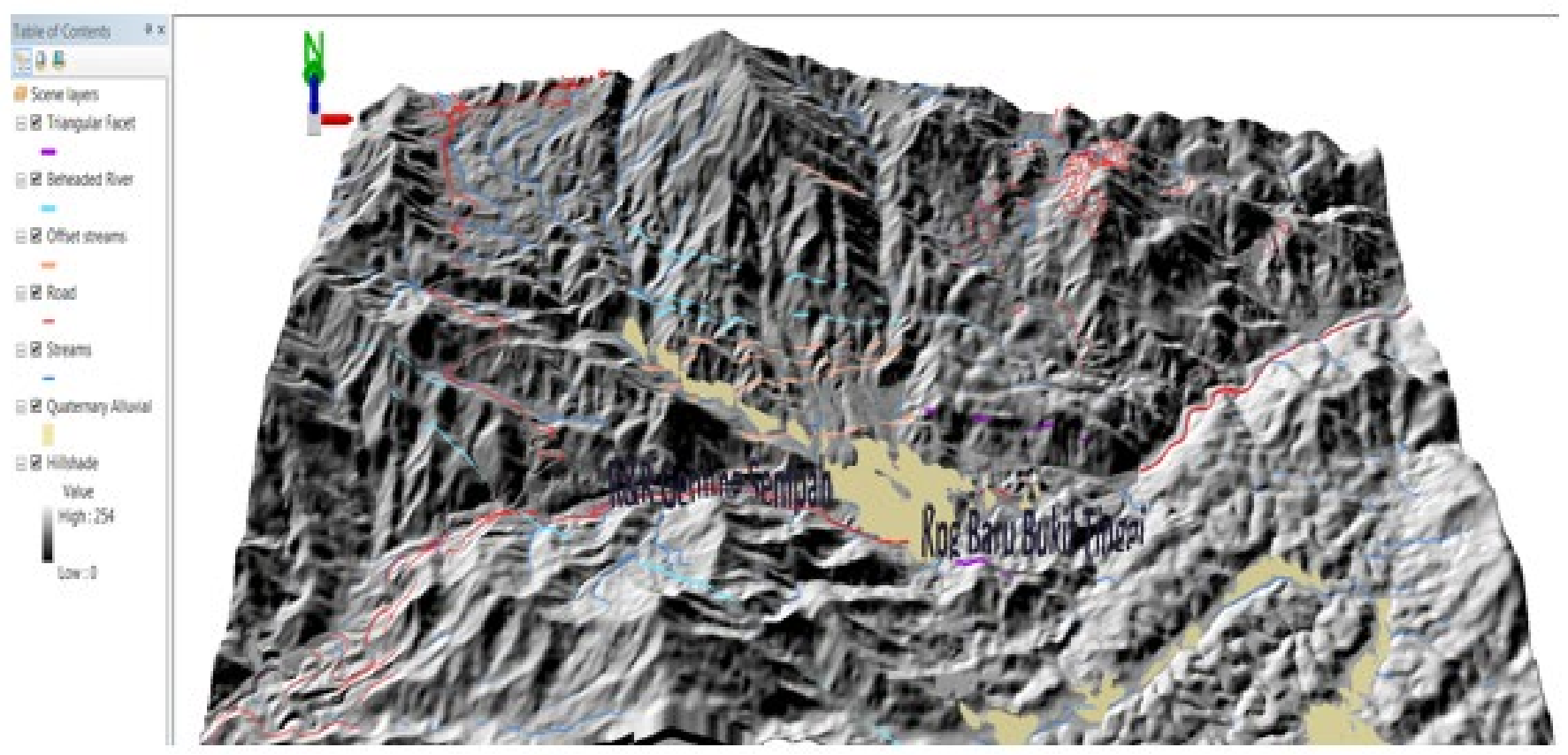

Figure 9: 3D view of the Bukit Tinggi region showing the flat lying Qa alluvial basins 


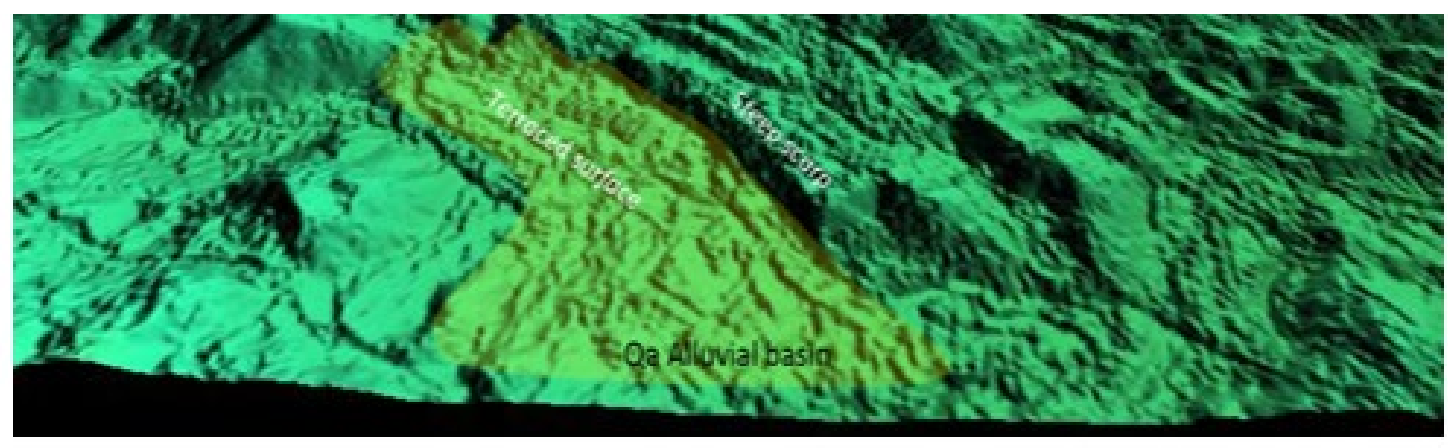

Figure $103 \mathrm{D}$ view showing the Qa alluvial basin with terraced surface bounded by steep scarps. Note the prominent lineaments bounding the basin

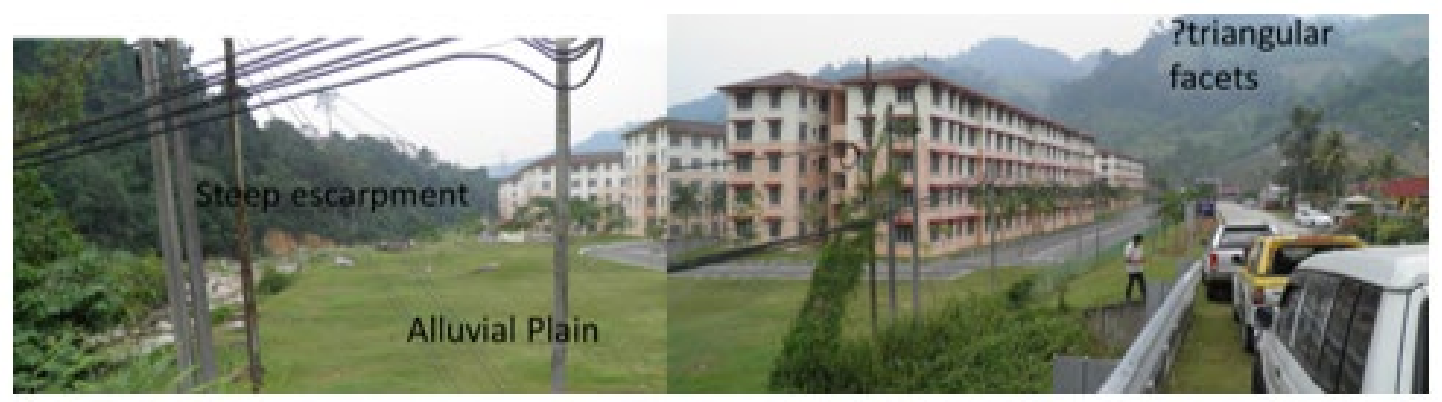

Figure 11 A photograph showing the Quaternary alluvial plain bounded by steep scarps.
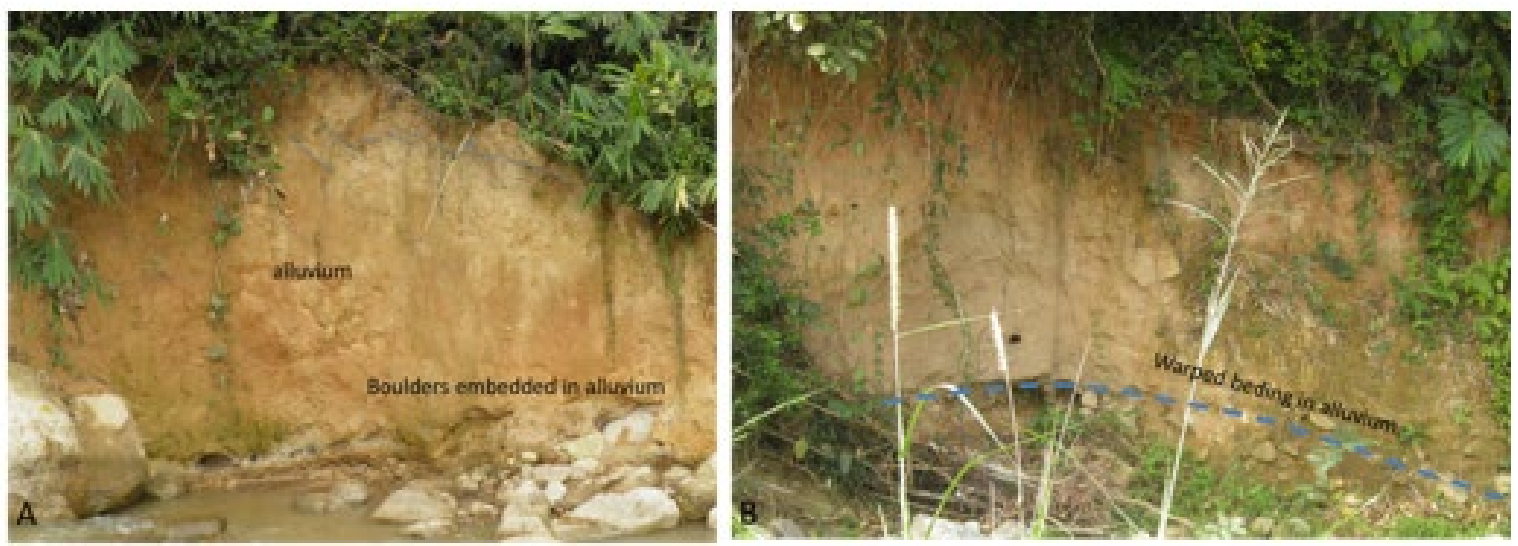

Figure 12 Alluvial deposits A) with boulders at the base and B) warped bedding, (location Taman Bukit Tinggi) 


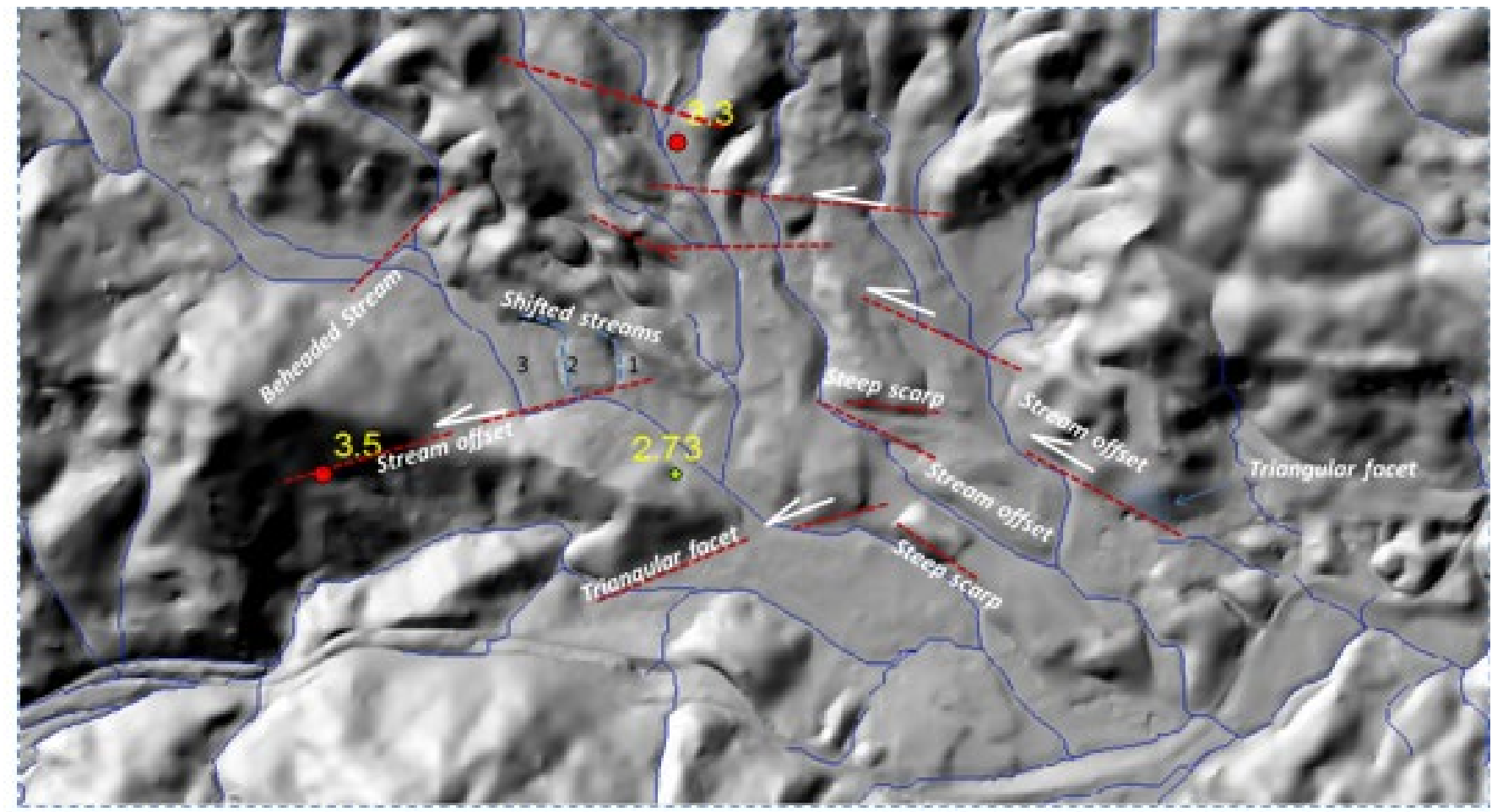

Figure 13 the distribution of various active geomorphic features and suggested sense of slip along the interpreted sctive fsult segments slong Bukit Tinggi fsult zone.

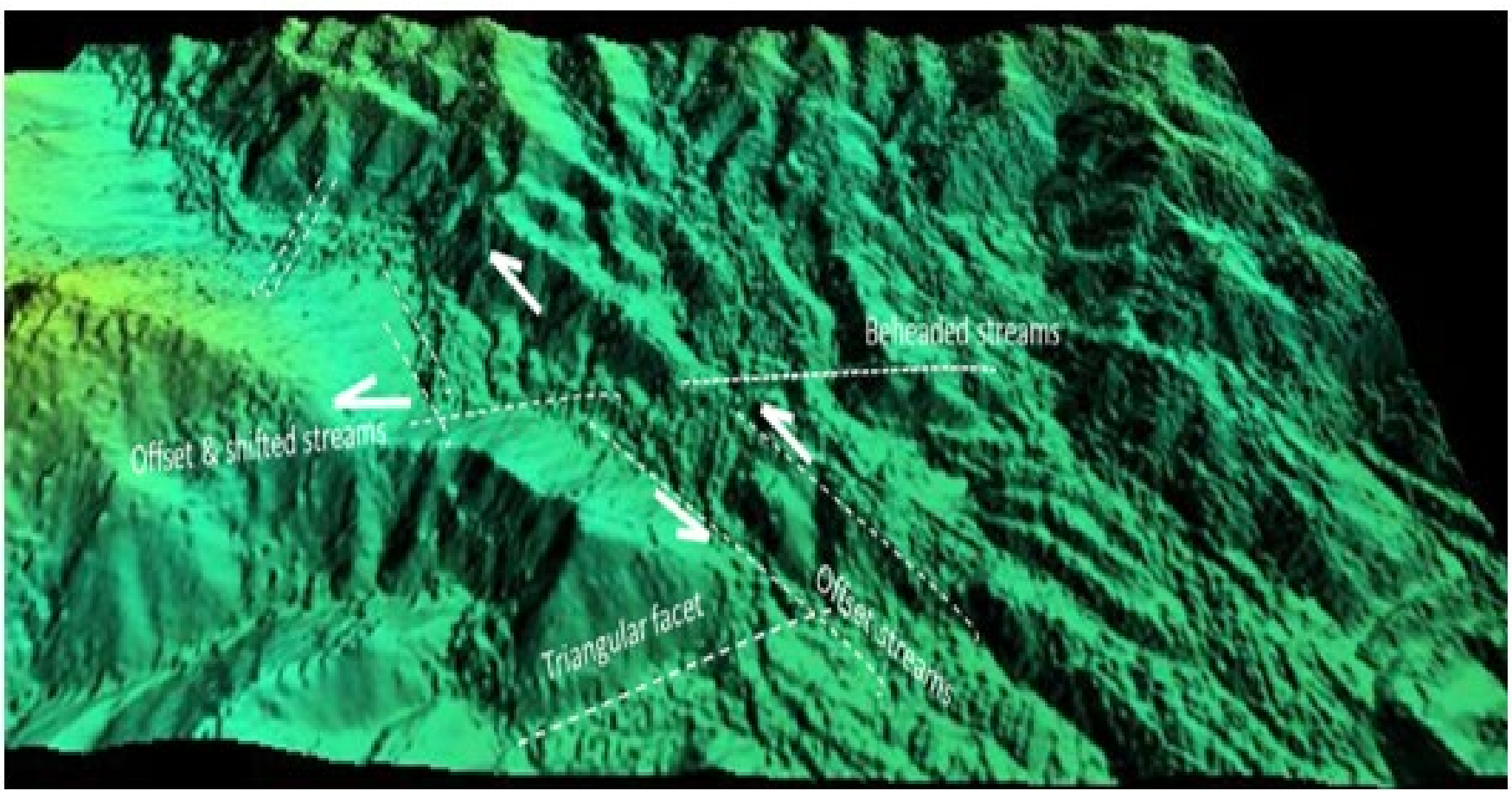

Figure 14: 3D DTM of Bukit Tinggi area showing young active tectonic landforms such as stream offsets, beheaded streams and migrating streams where these offsets occur along lineaments that pass through earthquake epicentres. 


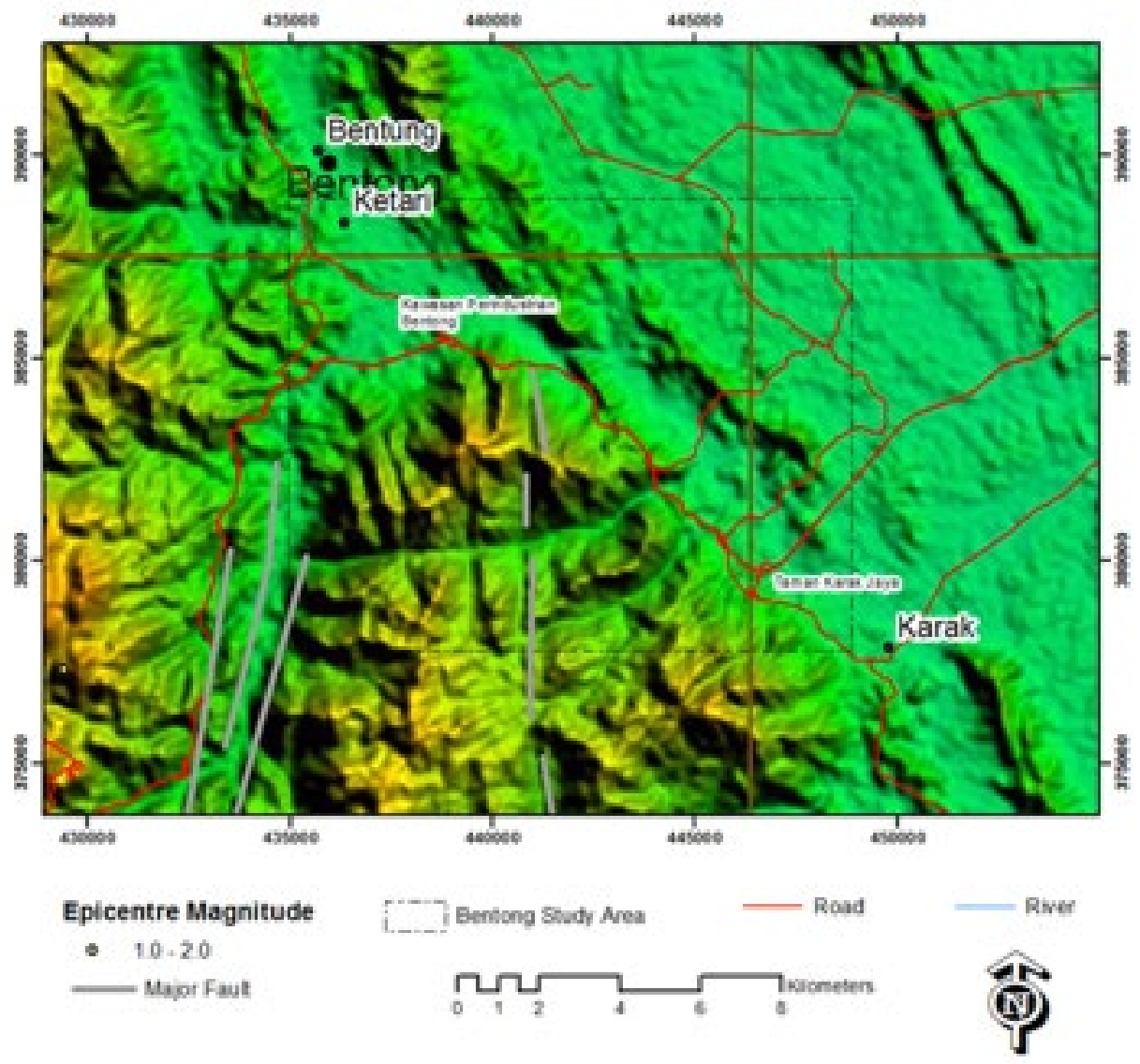

Figure 15 SRTM of Bentong and Karak areas.

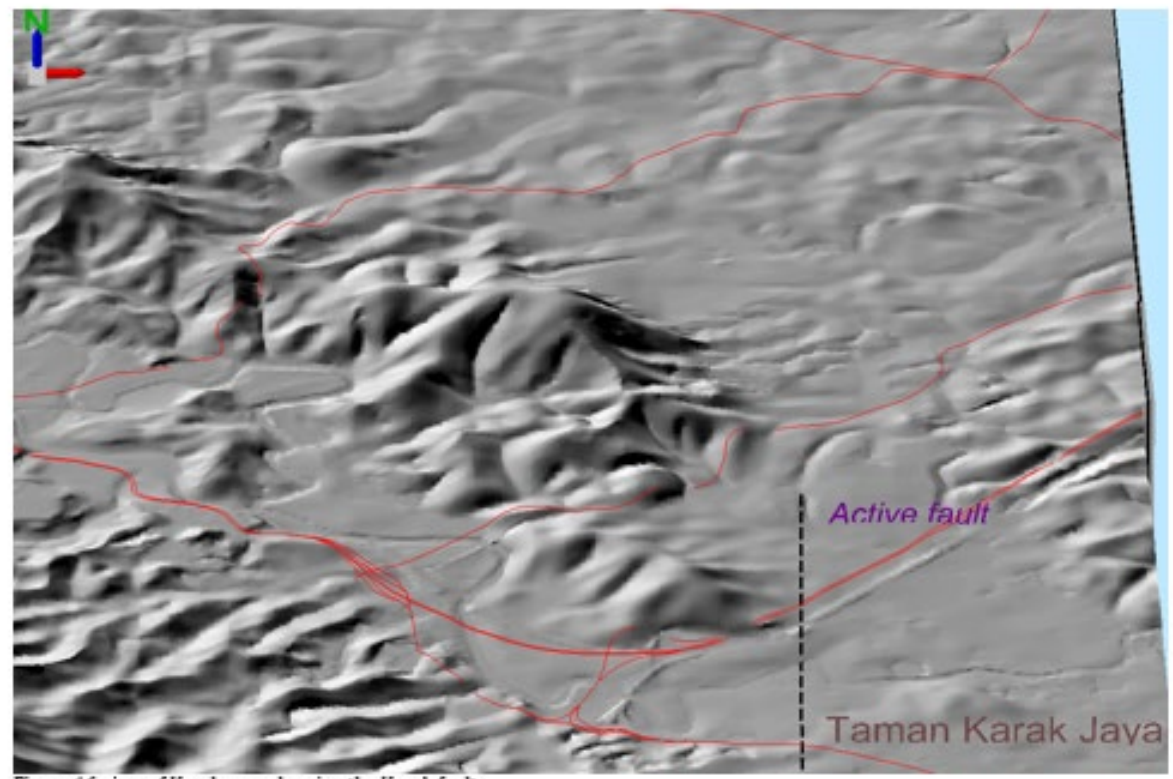

Figure 16 view of Karak area showing the Karak fault 


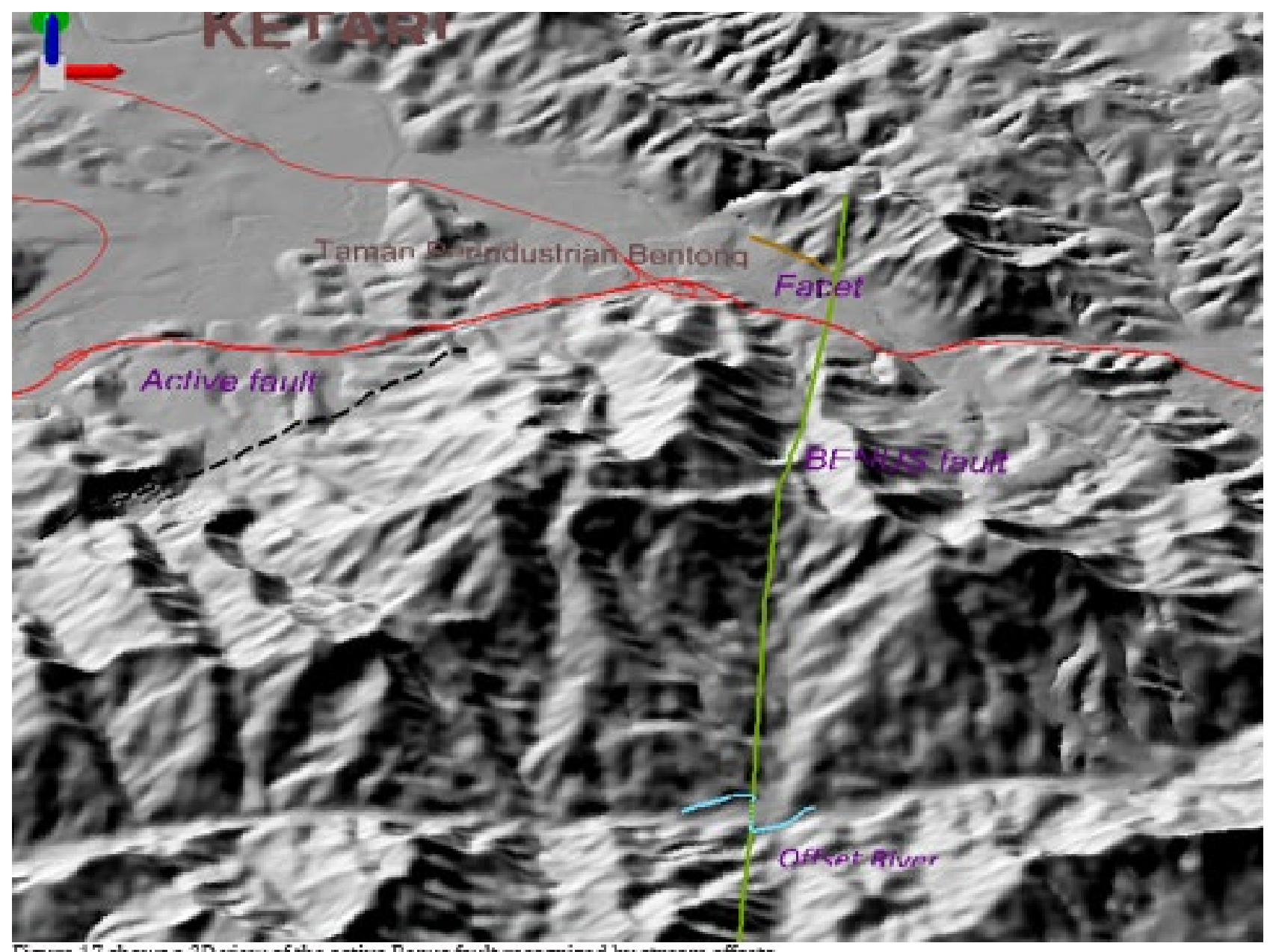

Figure 17 shows a $3 \mathrm{D}$ view of the active Benus fault recognized by stream offsets. 